'llu. Revista de Ciencias de las Religiones

ISSN: $1135-4712$

https://dx.doi.org/10.5209/ilur.75198

\title{
Maternal Bodies in the Biblical Books of Samuel and Kings: Notes on the Representation of Maternity in Crisis Contexts
}

\author{
Claudia Andreina D’Amico Monascal ${ }^{1}$
}

Recibido: 7 de mayo de 2020 / Aceptado: 18 de febrero de 2021

\begin{abstract}
Although motherhood is the female destiny par excellence in the biblical narrative, it is an experience only accessible through a male point of view. In order to reflect on the problems of representation of the maternal body in the Hebrew Bible, I propose an analysis of different maternal characters present in the books of Samuel and Kings. My reading aims, on the one hand, to identify the features that define the maternal in the biblical text and, on the other hand, to offer an approach that allows to point to the implications that the crisis context the texts reflect have on the picture of the actions and the destinies of these female characters.
\end{abstract}

Keywords: Hebrew Bible, Maternal bodies, Maternal ideal, Conflictive mothers, Samuel, Kings, Crisis.

\section{[esp] Cuerpos maternos en los libros bíblicos de Samuel y Reyes: notas en torno a la representación de la maternidad en contextos de crisis}

Resumen. Dentro de la narración bíblica, la maternidad se presenta como el destino por excelencia de las mujeres y, sin embargo, es una experiencia que conocemos únicamente a través de un discurso eminentemente masculino. A partir de una lectura de distintos personajes maternos cuyas historias se encuentran dentro de los libros de Samuel y Reyes, pretendo reflexionar acerca de la problemática de la representación de los cuerpos maternos. Mi propuesta persigue un doble objetivo: por una parte, identificar las características de lo materno que encontramos en el texto bíblico y, por otra, ofrecer un acercamiento que permita señalar las implicaciones que el trasfondo de crisis ideológicas y políticas del texto tiene sobre la presentación de las acciones y el destino de estas mujeres.

Palabras clave: Biblia hebrea, cuerpos maternos, ideal materno, madres conflictivas, Samuel, Reyes, crisis.

Summary. 1. Introduction. 2. The Maternal Ideal. 3. Conflictive Mothers. 4. The Maternal Body as a Literary Tool. 4.1. Political Legitimation. 4.2. Representation of Chaos. 5. Conclusions. 6. Bibliography.

Cómo citar: D'Amico Monascal, C.A. (2021). Maternal Bodies in the Biblical Books of Samuel and Kings: Notes on the Representation of Maternity in Crisis Contexts, en Ilu. Revista de Ciencias de las Religiones 24, 9-19.

1 Investigadora independiente.

Correo electrónico: cludamico@gmail.com

ORCID iD: https://orcid.org/0000-0003-4380-6082 


\section{Introduction}

Maternity and the maternal are concepts that deeply affect the lives and bodies of women, as they emanate from a gender dynamic that benefit male interests. Especially because, as different feminist theories have recognized over time, maternity has been historically constructed as women's sole destiny ${ }^{2}$ : so the biological possibility of female bodies to give birth became a social obligation through myths such as that of maternal love and instinct.

Therefore, is important to differentiate between motherhood as experience and as institution, as Adrienne Rich did in her famous book Of Woman Born. Motherhood as institution, contrary to women own experiences and views of pregnancy, is mediated by a collective male conscience ${ }^{3}$. First, what we find in the institution of maternity is the reduction of women to the realm of biological reproduction and the negation of their subjectivity, their desires and their identities outside the maternal role secondly, an ideal understanding of motherhood in which there is no place for fear, danger, disillusionment or detachment ${ }^{5}$; and, finally, the construction of the maternal figure as a stereotype that homogenizes and suppress all difference while subjecting the feminine ${ }^{6}$.

Feminist biblical scholars have also pointed out that maternity is constructed in the biblical books in accordance with the ideology that underlies the text, especially with the need to maintain and guarantee the survival of patriarchy ${ }^{7}$. This would explain why the maternal figure is the most common of the female characters in the biblical narrations and also its positive representation within the text: they can appear as braver, more autonomous and/or decisive than women who are not mothers. The relevance of the maternal figure is clear, for instance, in the Deuteronomic family laws, where we find that both parents have the same functions when it comes to matters that concern the family, as well as a symmetry in the way both sons and daughters owe obedience to their progenitors (Deut. 21:18-20).

Based on this preeminence of the maternal role, my analysis has two main aims. On the one hand, to identify the features that define the maternal in the biblical books of Samuel and Kings and, on the other hand, to point to the implications that the contexts of crisis that these narrations reflect have on the literary representation of motherhood. To this end, I will read different stories paying attention to the way maternity is constructed over the female body. Since the body is the site where gender expectations and norms are imposed ${ }^{8}$, is important to use it as an object of study in order to underline the political discourses that have shaped female identities -such as the maternal- without taking into account the will and the experiences of real women.

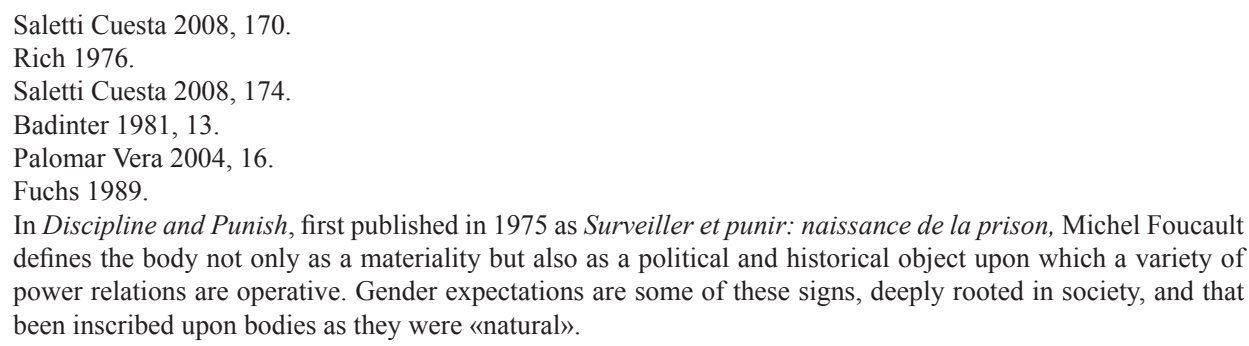
defines the body not only as a materiality but also as a political and historical object upon which a variety of power relations are operative. Gender expectations are some of these signs, deeply rooted in society, and that been inscribed upon bodies as they were «natural». 
Thus, through the bodies of the female characters I aim to point to what constitutes the maternal ideal, what is considered deviation from it, the possibilities that this ideal offers to women, and also the oppressions that goes along with it. Following the conclusions of this first reading, I will finally examine the relationship between the crisis background reflected in the text and the construction of motherhood, to propose some notes on the motivations behind the narrative and the role played by the maternal bodies within biblical discourse.

\section{The maternal ideal}

In the Hebrew Bible, the vital definition of womanhood occurs when the man calls her hawwâ ('mother of all life') in the book of Genesis (3:20). So, from the very beginning, both the capacity of the female body to give birth and the specific needs of an androcentric society such as the Israelite, meaning the perpetuation of the paternal genealogy, cause motherhood to become the preferred -when not the soledestination for women.

This idea that maternity is a feminine role that has to be fulfilled, regardless of the particular reality of women, is already reinforced in the first story we find in the books of Samuel. The tale of wondrous maternity that initiates 1 Samuel stars a woman named Hannah (1 Samuel 1-3). Throughout all the narration we assist to a female drama, marked by anxiety and desperation caused by the infertility suffered by its protagonist and that lead her to elevate a cry directly to God (v. 11) .

The petition Hannah elevates to God is clear: she wants a child even if she has to consecrate him and give him to the divinity forever. At the beginning of her story, we are told that Hannah, although not yet a mother, enjoys all the advantages of being one: Elkanah not only favors her over Peninnah but it is also said that he loves her. Thus, her cry at the Temple reinforces the idea that maternity is a female role that has to be fulfilled regardless of the concrete reality of women. This is precisely one of the main characteristics of motherhood as an androcentric institution: it is established as «a stereotype that unifies all women under the same image» ${ }^{10}$; the image that being a mother is, sooner or later, the desire of every woman ${ }^{11}$.

The role motherhood plays in the literary evaluation of female characters is also evident in the scene where Phinehas' woman gives birth in the context of the war between Israelites and Philistines that has resulted in the death of her husband and her father and brother in-law. Shortly before dying in childbirth, the midwife tells her: «Do not despair, for you have given birth to a son!» (1 Samuel 4:20). The sufferings or the well-being of the mother are of no interest; nothing is more important than to fulfill the feminine role per excellence by providing a new male member to the community ${ }^{12}$. The story of the woman of Shunam (2 Kings 4:1-44) also insists in

9 Her suffering needs to be address in a context where infertility is an issue exclusively feminine and, as occurs with Hannah, the defining element of the woman who suffer it (Raphael 2008, 57s).

10 Moreno Seco and Mira Abad 2005, 19.

11 This is the only female feeling that we usually have access to while other like fear, pain, or even the possibility of not wanting children are silenced (Rich 1996, 64s.).

12 We can ask ourselves what would have happened if the child was a girl. Generally, the Hebrew Bible does not tell stories about the relationship between mothers and daughters. For instances, is striking the maternal absence in the stories of Jephthah's daughter, Tamar or Michal. 
the idea that it is the desire of every woman to have children. We don't have any evidence of her needs, but maternity is imposed on her as a destiny and meaning anyways: after Gehazi informs the prophet about her lack of progeny, Elisha announces that she will be with child, although she never utters her intention or desire of being a mother, and seemingly on the assumption that women are mothers by nature (vv. 12-17) ${ }^{13}$.

Once the woman gives birth, the maternal ideal is represented as a body who gives itself to the child, normally when his life is endangered ${ }^{14}$. As the guardian of her children, the mother uses all means at her avail to guarantee their well-being. This explains the efforts the woman of Shunam goes through to reach the prophet and confront him to make him resuscitate her child (vv. 28, 30), as well as the actions of Rizpah, whose body works as a shield that protects the corpses of her sons, providing care to them at the cost of her safety (2 Samuel 1:10-14). Finally, Bathsheba, the first maternal character in the books of Kings (1 Kings 1:1-31;2:13-23), is another example of an effective mother, capable of defending the interests of her son. Although she barely intervenes in the earlier story, when she becomes a mother we can see her acting and talking, mediating in favor of her son.

Hence, the biblical mother not only has the obligation to give life but also to preserve it. To meet this imperative she is represented putting all her efforts in getting pregnant and nurturing and protecting her sons, even to the point of facing the king of Israel, as we see the mother prostitute do in the famous story of the judgment of Solomon. The episode present two prostitutes who appear before the king to ask him to intervene in a quarrel between them: one of the women has unwittingly killed her newborn son, exchanged him with the son of the other and now both claim property over the living child (1 Kings 3:16-22). In order to settle the conflict, the king suggests cutting the baby in two to give each woman a half. One of the women decides to give up the fight in order to save the boy, revealing herself as the «true mother». Following the text, 'compassion' (rahamîm) is the feeling that moves her to action. In its singular form, rehem means 'womb' the uterus and, consequently, a biological and immutable fact that is part of the ideological framework that gives form to the concept of «the good mother» ${ }^{16}$.

\section{Conflictive mothers}

Aside from these more or less positive representations of maternity, the biblical texts also present other stories where the maternal figures are much more complex and problematic. In the books of Kings, especially, these maternities are presented as inversions of the maternal ideal, materialized through the actions and bodies of marginal and liminal women.

So, we have the second prostitute in the episode of the judgment of Solomon (1 Kings 3: 16-28). Unlike the first prostitute, this woman doesn't contest the royal

Saletti Cuesta 2008, 173.

Fuchs 1985, 133.

Trible 1978, 33 .

16 But women are not the only ones who feel compassion. Men (and even God) may also have compassion, so it is not just a «biological» grounds for the feeling, but also a cultural depiction where that kind of feeling becomes an ideal or archetype. 
ruling and agrees to split the child in two (v. 26). Her display of cruelty, in clear contrast with the sacrifice of her opponent, violates all the principles that constitute the role of the biblical mother. In a reversal of roles, her body does not offer itself to the other, but demands the body, her corresponding half, of the other.

As in the case of the prostitute mothers, the episode of the cannibal mothers of 2 Kings 6:26-31 also offers us with a story of two women confronted with the life of a child. The general context in which the narrative unfolds is the terrible famine that ravages Samaria due to the siege carried on by Ben-Hadad, king of Aram. The dehumanizing nature of war and the marginal condition of the female characters lead them to come to a grisly agreement: they will feed on their children in order to ensure their survival. Confronted with a dramatic vital situation, the maternal condition is altered, and these mothers do the completely opposite of what is expected from a normative mother, whose body is the provider of food and care par excellence ${ }^{17}$.

I bring one last example that presents the inability to guarantee the life of the child as a maternal failure, that of the episode of king Jeroboam's wife (1 Kings 14:1-20). When the king's son falls sick, he sends his wife to ask the prophet Ahijah about the future of their child. However, we never hear her talk and so she is incapable of intervening in the story; the fate of the house of Jeroboam is sealed. Since the death of the child takes place at the exact moment she returns home (vv. 17-18), there is a clear connection between her actions and the destiny of her son. As the main responsible for the life of her son, the woman failure as a mother always results in his death.

Finally, and as we have seen, the instances when women cannot have children are also problematic, as the emphasis made at the end of their stories prove. It is the case of Tamar (2 Samuel 13), daughter of David, who after her incestuous rape is condemned to live in despair the house of her brother Absalom, or that of Michal, who we know that remains childless after being rejected by David (2 Samuel 6: 23).

All these maternal figures are depicted as scary, negative versions of the sanctioned image of the biblical mother: they do not bring life but death, both by their own hands or by the ineffectiveness of their agencies. If mothers have been socially constructed as naturally nurturing or caring, what we find here are women who seem to neglect the wellbeing of their children or that are unable to fulfill the role assigned to them.

\section{The maternal body as a literary tool}

«In that time there was no king in Israel and each did was what good at his own eyes» (Judges 21:25). With this sentence, the author finalizes the convulsive period of the Judges and delves into the story of the instauration of the monarchy, its rise and its decadence. Throughout the books of Samuel and Kings we are presented with enough challenging episodes in the history of biblical Israel in which the institutions that sustain the identity of the people are at stake: first, monarchy itself is in question in the narrative of David's rise to power and his troublesome succession and, second, the cult of Yahweh and, consequently, the promise of the land made by God. The actions of the kings are evaluated by the author and are intertwined to

17 Lagarde y de los Ríos 2011, 394. 
compose a story that explains the fall of Jerusalem and the Assyrian and Babylonian exiles.

As many scholars have recognized, the collective memory that binds ancient Israel together as a community is presented as a literary tale, by means of artful devices that allow the authors to construct and transmit their own meanings, as well as to establish a hierarchy of subjects and knowledge ${ }^{18}$. Within these literary tools, the use and representation of female bodies and stories is revealed as a means for symbolizing conflicts in the context of male narratives.

We can find the origin of this use of the female body, especially maternal bodies, in the gender inequality that the text reflects. Within androcentric societies, the man, as a center and measure of all things, positions himself as subject in opposition of the woman, who is marked as «other» ${ }^{19}$. Thus, female alterity is constructed on the negativity the difference has in a variety of discourses, from the original myths to today's technological and scientific discourses; in all of them, woman's inferiority is conceptualized, explained, justified, and validated, always from the male point of view. One of these discourses is, as we have seen already, that of maternity.

Female reproductive body has always been a site of fear and fascination and one of the bases of what Barbara Creed calls «the monstrous feminine» ${ }^{20}$, and of the relation between female body and abjection ${ }^{21}$ :

Like the abject, maternity is the splitting, fusing, merging, and fragmenting of a series of bodily processes beyond the will or control of the subject. Maternity is both socially productive, in so far as the mother 'produces' the social matter which constitutes social subjectivity; and, on the other hand, maternity is also a breach, or rupture, in the symbolic (...) It is a region which requires territorialization and mark by the proprietorial name of the father; that is, it must be restricted and contained in order for the father's law to be accepted ${ }^{22}$.

Due to this ambivalence, the female body is subject to two representations within male discourses: the model of order and security and the model of chaos and danger: as the embodiment of the maternal ideal or as a paradigm for the monstrous ${ }^{23}$, it has the potential to symbolize both normalcy and liminality. In an intricate relation between individual and society, women's correct or incorrect interpretation of gender roles and expectations that sustain the foundations of culture are used as a token of the good or bad functioning of the social fabric. So, the correlation between the representation of female characters and the identity crisis provoked by the exile is possible.

Thus, all the power dynamics that we find in the books of Samuel and Kings, as well as the uncertainties that the political and migratory changes bring on the people, can help us define the way the women are represented, especially when it comes to maternal characters. For the present study I will consider two main uses of the maternal body in the contexts of crisis the text reflects.

Alter 1983, 116s.

Braidotti 2004, 13.

Creed 2007.

Julia Kristeva, in her book Powers of Horror $(1982,4)$, defines abjection as what «disturbs identity, system order. What does not respect borders, positions, rules? The in-between, the ambiguous, the composite».

22 Gross 1990, 96

23 Creed 2007, 83. 


\subsection{Political legitimation}

Through the construction of a maternal ideal that, as we have seen, is characterized by women who yearn for a child at all costs and who watch over him in any circumstance, the author is able to positively validate and give sense to the political and religious changes that take place within the books of Samuel and Kings. Thus, the decision to present the birth of Samuel (1 Samuel 1-2) as an annunciation type-scene is not casual. Following Robert Alter, this type-scene always concerns the birth of a biblical hero that will change or will intervene in a special way in the history of Israel ${ }^{24}$.

By means of the deficient body of Hannah, the mother, and the divine intervention that happens as a consequence of her desperate call, the text insists in the exceptional nature of Samuel, in the moment when the transition from the times of the Judges to the new times of kings and prophets takes place. Precisely, Samuel will play a key role within this turn of the religious paradigm since he acts as the last judge before the institution of the monarchy and the first great prophet since Moses.

Similarly, one of the great opportunities to prove the worth of the prophet Elisha as the intermediary of Yahweh happens in the episode of the woman of Shunam (2 Kings 4:8-37). Again we find a story where the female body is presumed defective, although the text never makes clear why she does not have kids; on this ground, the prophet makes his miracle and grant the woman with a child. But the true validation of the prophet occurs when the kid dies and the worried mother forces him to act: once she becomes a mother, her role is to safeguard her child's life, so she forces Elisha to perform a new miracle. Only when the prophet resuscitates the boy, the woman prostrates herself at his feet and makes visible her recognition of his power as a miracle worker (v. 37).

Solomon's claim to the throne is also justified through the figure of a mother; in this case his own mother, Bathsheba. Committed with her maternal role, Bathsheba confronts an old David to ensure that it will be her son and not Adonijah, the legitimate heir ${ }^{25}$, who will replace their father as king (1 Kings 1:15-31). Although the text barely allows Batsheba to speak, when it is her turn to fight for the future of Solomon she is responsible for informing the readers about a royal promise we have not heard before: according to Bathsheba, David has agreed to name Solomon his successor, in detriment to his older brother (vv. 17-21). And she is the one who finally mediates in the subsequent conflict between Adonijah and Solomon that ends with the death of the former and the consolidation of the second as king of Israel (1 Kings 2:13-23).

A mother figure is also crucial in the scene that illustrates Solomon's wisdom and ability to rule. In the episode known as the Judgment of Solomon, (1 Kings 3:16-28) the king is able to anticipate the reaction of the «true» mother thanks to the pervasive, preconceived idea that she will save the child even against her will. That means that Solomon's sentence is effective because it is based on the idea of maternal love that is imposed on the female characters.

In all these stories the maternal body is represented as a safe place where male characters are able to vindicate and justify their power claims. In her obedience, the mother makes possible not only the birth of the biblical hero but also his survival and, ultimately, contributes to the legitimation of the political and religious discourse of the text.

Alter 1983, 121.

Adonijah is the oldest living son of David (Cogan 1988, 157). 


\subsection{Representation of chaos}

Nevertheless, when the female body doesn't stick to the model of the normative mother, it can turn into a symbol of death and danger. Since the mother not only gives life but also has the power to take it away -by refusing to feed her son, for instance- her body becomes the perfect scenario to represent contexts of conflict and uncertainties. For this reason, the author is able to compose his narrative of rejection and divine punishment that support his history of biblical Israel, both through the female barren body and the inversion of the maternal ideal.

Thus, Phinehas' wife, member of Eli's rejected priestly staff in 1 Samuel, can only give birth in a catastrophic context. With her last breath, just before dying, she names her son «Ichabod» or «Where's the Glory? » (vv. 21-22) ${ }^{26}$, alluding to the disaster her own family and the Israelites are facing at the war against the Philistines. As the two sides of the same coin, the Hannah episode presents the divine intervention not only as the means to overcome her infertility, linked with death within the feminine sphere, but also as a symbol of election and divine sanction, while in the tale of Phinehas' wife, Yahweh's absence explains why she gives life only to face death afterwards. Emphasis is made through timing: it is right after the report of the news of the death of the Elides and the loss of the Ark that Phinehas' wife death takes place: over her dead body and her decision to give her son a name linked with her sufferings, the extinction of the house of Eli $i^{27}$ is confirmed in favor of the prophet Samuel and the change of religious paradigm is fulfilled.

As it happens between Samuel and the house of Eli, female characters also play a role in the representation of the dynamics of election and rejection that are set between the houses of David and Saul. So, in order to justify David's rise to power and disqualify Saul and his dynasty, the author denies Michal, at the same time Saul's daughter and David's wife, any possibility of having offspring. The last time we see her, she is estranged from David, incapable of becoming a mother and her empty uterus only leads to the death, in this case symbolic, of the Saulid dynasty (2 Samuel $6: 23)^{28}$.

With the division of the kingdom of Israel (1 Kings 12) and the chaos that eventually looms over the people, ineffective mother figures appear, such as Jeroboam's wife (1 Kings 14:1-20). When the king's son falls ill, she is sent to the prophet Ahijah to ask for child's future. Although in a disguise, she is soon recognized by Yahweh and his prophet (vv. 5-7). We never hear her voice but the voice of Ahijah prophesying the end of Jeroboam's rule and dynasty. When she leaves the prophet's house, her maternal body not only carries the terrible message but, in a reversal of roles, also death to her child (vv. 17-18). Through her failure as a mother, the biblical authors depict Jeroboam's loss of Yahweh's favor and «contributes to the characterization of the post-Solomonic kings as displeasing to both Lord and the narrator $(\ldots)\rangle^{29}$.

As in the case of Jeroboam's wife, Athaliah also brings death to her family in 2 Kings 11:1-20. When she hears about the death of her son Ahaziah (the king of Judah at the death of his father) by the hand of the usurper Jehu, she orders the killing of all

26 McCarter 1980, 116.

27 «The death of the Elides is the fulfillment of the divine words of 2:27-36 (..) and resolve the problem in Israel of which 2:12-17, 22-25 speak» (Miller Jr. and Roberts 2008, 50.)

28 Schipper 2007, 104s.; also McKenzie 2000, 137s.

29 Reinhartz 1994, 60. 
the surviving members of the royal family in order to become queen (v. 1). Only her grandson, Joash, survives, thanks to the intervention of his aunt Jehosheba (vv. 2-3).

Contrary of what we would expect from a grieving mother ${ }^{30}$, Athaliah acts as a typical male ruler from the ancient Near East who plans to grab the power at all costs and, as we saw Solomon do before (1 Kings 2: 25), decides to overcome any obstacle that stands between her and the throne. But unlike what happens in the Solomon's story, there does not seem to be a justification behind Athaliah's actions. In clear opposition, the figure of Jehosheba acts as a surrogate mother taking care of the child in danger. Her efforts to protect Joash allow him to be crowned as king of Judah, after Athaliah perishes at the hands of the inhabitants of Judah (vv. 15-16).

This contrast helps with the characterization of Athaliah's transgressive character. As the daughter of the much-hated Jezebel, Athaliah bears with her the stigma of the enemy of the religion and the monarchy of Israel, accusation that is confirmed when she crowns herself as queen of Judah as a result of her killing of the royal seed (being her grandchildren), subverting all that constitutes order and identity within biblical Israel.

Finally, the cannibal mothers (2 Kings 6:26-31) work as a representation of a besieged world that is at risk of disappearing. These mothers, contrary to the idea that the maternal body is meant to nurture children, agree to eat the flesh of their sons to survive. In this episode, maternal cannibalism, as the clearest representation of the inversion roles of provider-devourer, is a symbol of a context of social violence, where being cheated on anthropophagy is an acceptable plea to bring before the king (vv. 28-29).

The scene of a mother complaining to the king can thus be read as a sort of degraded deconstruction of 1 Kings 3 , where stable categories of «justice» or «compassion» become irrelevant. The fracture of the «natural» order that is embodied in the maternal happens in a disrupted reality, within a society in crisis whose rulers are incapable of offering solutions to the problems faced by its individuals ${ }^{31}$.

The problematic maternities these women represent appear in context of profound political, religious or identity crisis. The inversion of the maternal role or the ineffectiveness of the maternal body are presented as symbols of chaos, condemnation and abandonment. So, through them, we can read the justifying account of the fall of the southern and northern kingdoms that the biblical authors try to explain as a punishment of the sinful acts of their rulers.

\section{Conclusions}

When we read the biblical stories that have mothers as leading characters, is important to look for the role women play within the literary discourse of the text. Although we can only speculate about the life of women in the Ancient Israel, we can look for the gender ideology that permeates the text. First, as female alterity is embedded in women's bodies all its functions are domesticated through a series of rules and expectations that void the singularity of female realities. And second, women's

30 And we can recall here the actions of Rizpah, Saul's wife, who protected the corpses of her sons with her body for days and nights until King David attended her request of giving them proper burial.

31 Lansine 1991, 45s. 
subordinate nature within androcentric societies allows for the use and manipulation of these same rules and expectations in order to give meaning to their own discourses and ideologies. So, what we find in these biblical stories is the male fiction of a female experience that remains inaccessible to the reader.

As we have seen, the books of Samuel and Kings are part of a tragic tale and the sense of catastrophe does not diminish through its pages: although figures such as Josiah are praised by the author and we find constant allusions to the concept of the «lamp of David», biblical Israel is incapable of maintaining faithful and, eventually, is divinely punished and exiled from the land of Canaan. Two big milestones take place in the narrated history: while the books of Samuel present the complicated transition of power from the Saulid to the Davidic dynasty, and the succession struggles between David's heirs, in the books of Kings foreign invasions are intertwined with the internal failure of the monarchies of a divided kingdom. In this context of instabilities and uncertainties is where our female stories take place.

Thus, by means of the literary appropriation of women's biological capacity to give birth, it is possible to construct a maternal ideal that is presented as «natural» and that embodies the good functioning of the social fabric. On one side, women who comply with the principles that constitute the biblical institution of maternity stand for the divine and literary approval of their children (i.e. 1 Samuel 1-2; 1 Kings 1-2). On the other side, the author builds strange and grisly scenes on the fracture of the foundations of that same maternal ideal: births that are followed by death (1 Samuel 4:19-22), cannibal mothers (2 Kings 6:26-31) or barren women (2 Samuel $6: 23)$. In this case, the «natural» order embodied in the female bodies cracks and give way to chaos; the same chaos in which biblical Israel is submerged as a result of the exile. The same chaos any community suffers when it is obliged to abandon all that constitute its own identity.

Female otherness gains visibility as the structures that support the social and religious system the biblical authors have constructed tumble down: as the current analysis has proven, the study of the female and maternal body allows us to identify not only the gender politics that underlie male discourses but also the discursive and literary coping with social and historical events that have left an imprint on the composition of the biblical books.

\section{Bibliography}

Alter, R., 1983, “How convention helps us read: The case of the Bible's Annunciation typescene", Prooftexts 3/2, 115-130.

Badinter, E., 1981, ¿Existe el amor maternal? Historia del amor maternal, siglos XVIII y $X I X$, Barcelona.

Braidotti, R., 2004, Feminismo, diferencia sexual y subjetividad nómade, edición a cargo de A. Fischer Pfeiffer, Barcelona.

Cogan, M.; Tadmor, H., 1988, II Kings. Anchor Bible vol. 09, New York.

Creed, B., 2007 ${ }^{6}$, The Monstrous-Feminine. Film, feminism, psychoanalisis. London - New York.

Fuchs, E., 1985, "The literary characterization of mothers and sexual politics in the Hebrew Bible" in A. Yabro (ed.), Feminist Perspectives on Biblical Scholarship, Chico, California, 117-136. 
Fuchs, E., 1989, Sexual Politics in the Biblical Narrative: Reading the Hebrew Bible as a Woman, Sheffield.

Gross, E., 1990, "The body of signification" in J. Fletcher and A. Benjamin (eds.), Abjection, Melancholia, and Love: The Work of Julia Kristeva, New York, 80-103.

Kristeva, J., 1982, Powers of Horror, New York.

Lagarde y de los Ríos, M., 2011, Los cautiverios de las mujeres. Madresposas, monjas, putas, presas y locas, Madrid.

Lansine, S., 1991, "Jehoram and the cannibal mothers (2 Kings 6, 24-33). Solomon's Judgement in an inverted world", JSOT 50, 27-53.

McCarter, P.K., 1980, I Samuel. The Anchor Bible, vol. 8, New York.

McKenzie, S.L., 2000, King David. A Biography. Oxford.

Miller Jr., P.D. and Roberts, J.J.M., 2008, The Hand of the Lord. A Reassessment of the "Ark Narrative" of 1 Samuel, Atlanta.

Moreno Seco, M. and Mira Abad, A., 2005, "Maternidades y madres: un enfoque historiográfico" in S. Caporale-Bizzini (cood.), Discursos teóricos en torno a la(s) maternidad(es), Madrid, 19-61.

Palomar Vera, C., 2004, “"Malas madres': la construcción social de la maternidad”, Debate Feminista 30, 12-34.

Raphael, R., 2008, Biblical Corpora: Representations of disability in Hebrew Biblical Literature, New York - London.

Reinhartz, A., 1994, "Anonymous women and the collapse of the monarchy: a study in narrative technique" in A. Brenner (ed.), A Feminist Companion to Samuel and Kings, Sheffield, 43-66

Rich, A., $1995^{10}$, Of Woman Born: Motherhood as Experience and Institution, New York.

Saletti Cuesta L., 2008, "Propuestas teóricas feministas en relación al concepto de maternidad", Clepsydra, 169-183.

Schipper, J., 2007, "Disabling Israelite leadership. 2 Samuel 6:23 and other images of disability in the Deuteronomistic History" in H. Avalos, S.J. Melcher y J. Schipper (eds.), This Abled Body: Rethinking Disabilities in Biblical Studies, Atlanta, 104-13.

Trible P., 1978, God and the Rhetorics of sexuality, Philadelphia. 